\title{
CLINICAL AND BIOCHEMICAL STUDIES ON MUTANT RED CELL ENZYMES MAINLY ASSOCIATED WITH HEMOLYTIC ANEMIA
}

\author{
(The Japan Society of Human Genetics Award Lecture)
}

\author{
Shiro Miwa \\ Department of Internal Medicine, Institute of Medical Science, University of Tokyo, \\ Shirokanedai, Minato-ku, Tokyo 108, Japan
}

\section{Introduction}

I feel it a great honor to receive The Japan Society of Human Genetics Award of this year. The initiation of my works on red cell enzyme abnormalities associated with hereditary hemolytic anemia dates back to 1960 , when I began to work with Dr. W.N. Valentine at the University of California at Los Angeles (UCLA). We were lucky enough that we could discover pyruvate kinase (PK) deficiency hemolytic anemia in the following year (Valentine et al., 1961; Tanaka et al., 1962). After came back to Japan, I was able to continue and develop the studies in this field owing to the cooperation of my colleagues as well as kind advices from many of my seniors. Especially, Dr. S. Shibata's pioneer works on hemoglobinopathies in Japan encouraged me very much. In this lecture, I would like to follow my trail of my works.

\section{Discovery of Pyruvate Kinase Deficiency}

Selwyn and Dacie (1954) developed the autohemolysis test and found that some cases of so-called congenital nonspherocytic hemolytic anemia showed a peculiar pattern in this test. Red cells of these cases showed greatly increased hemolysis after 48 hours' incubation at $37^{\circ} \mathrm{C}$ which was not correctable with the addition of glucose. They classified these cases as Type II of congenital nonspherocytic hemolytic anemia. From this result, they predicted that something is wrong with glycolysis of the red cells in Type II cases. Meanwhile, it was found that red cell glucose 6-phosphate dehydrogenase (G6PD) was deficient in Negro cases who show drug-induced acute hemolysis after taking anti-malarial drugs such as primaquine (Carson et al., 1956). Thus, in late 1950s, biochemical studies of red cells attracted hematologists' attention quite a bit. In 1960, in Dr. Valentine's

Received January 10, 1980 
laboratory, we made a plan to check the activities of as many red cell enzymes of the Embden-Meyerhof glycolytic pathway as possible on cases with so-called Type II congenital nonspherocytic hemolytic anemia, with an intention that some kind of enzyme deficiency should be found in Type II cases. At that time, I was impressed by Drs. Löhr and Waller's works of Marburg, Germany, on red cell enzymes which were on Klinische Wochenschrift (Löhr et al., 1957). They have already developed the methods for the determination of all the red cell enzyme activities of the glycolytic pathway. To tell the truth, we mainly followed their methods. In February, 1961, we found that the activity of pyruvate kinase was markedly decreased in the red cells of a 26 years old Caucasian painter who had a Type II congenital nonspherocytic hemolytic anemia. Family study in this case disclosed that the father, mother, all of the children and some of the siblings had about halfnormal red cell PK activity without any clinical symptoms, indicating that this disorder is inherited by an autosomal recessive trait. Seven cases with this disorder were found by us within a year. We also found that the PK activity of the patients' leukocytes was entirely normal (Valentine et al., 1961; Tanaka et al., 1962). The latter finding was later confirmed by Koler et al. (1968) showing that the red cell PK and leukocyte PK from normal human subjects showed different kinetic properties and by Imamura and Tanaka (1972) that they showed different electrophoretic mobilities.

In this regard, I would like to emphasize just one point. Why the discovery of PK deficiency was all to our credit and the German investigators like Löhr and Waller could not find it earlier than us in spite of the fact that they had been ahead of us by four years in setting up red cell enzyme assays? It should have not been caused by the difference in frequency of the disorder between the U.S.A. and Germany, because many cases with this disorder were reported later from Germany. I think the reason for it is that Dr. Valentine had been working mainly with leukocyte enzymes and hence, we were accustomed to set up the assay methods of both red cell and leukocyte enzyme activities at the same time after carefully separating leukocytes from red cells. This is especially important for PK assay because leukocyte PK activity is entirely normal in red cell PK deficiency and also because one leukocyte has about 300-fold PK activity as compared with the activity of one normal red cell. If one is careless in separating leukocytes from red cells, one is apt to overlook PK deficiency due to the activity of contaminated leukocytes. I presume this might have happened in German investigators even they had encountered PK deficiency cases earlier than we had.

\section{Progress of the Studies on Pyruvate Kinase Deficiency in Our Laboratory}

Just before coming back to Japan, I was confident that there must be PK deficiency in Japan, and I decided to continue red cell enzyme studies. I was able to find the first PK deficiency case in Japan in 1965 (Miwa and Nagata, 1965a). In 
1965, Minakami, Yoshikawa and their colleagues developed simple enzymatic methods for the determination of red cell glycolytic intermediates and adenine nucleotides (Minakami et al., 1965). We adopted these methods, and this soon resulted in the discovery of a PK deficiency case which showed an even higher than normal enzyme activity determined by the conventional assay method. We found this case because of the accumulation of glycolytic intermediates previous to the step catalyzed by pyruvate kinase as well as a decreased amount of ATP in the patient's red cell. It soon became clear that the red cell PK of this case was kinetically abnormal because it had a markedly high Michaelis constant for the substrate phosphoenolpyruvate $\left(\mathrm{K}_{\mathrm{m}}\right.$ for PEP). We reported this case as "functionally abnormal PK deficiency" (Ohyama et al., 1969). It was unfortunate to us that one year earlier than this, Paglia et al. (1968) reported a case who showed high $K_{m}$ for PEP, although our study was done independently from theirs. At any rate, it became apparent that like G6PD deficiency (WHO Scientific Group, 1967), at least some PK deficiency cases were caused by mutant PKs.

At this point, we felt that a more direct approach than kinetic studies was desirable to confirm the evidence of structural gene mutations in this disease. There had been several previous reports of electrophoresis of kinetically abnormal red cell $\mathrm{PK}$, but we were unaware of any reports that clearly indicate inherited molecular abnormalities of red cell PK with abnormal electrophoretic mobility. Imamura and Tanaka (1972) developed a very good electrophoretic method which use thin layer polyacrylamide gel for $\mathrm{PK}$ isozyme studies. We quickly performed a cooperative study with them. A liver biopsy specimen of a PK deficiency case revealed to show clearly different mobility of liver-type (L-type) PK from that of the normal (Imamura et al., 1973). Soon after this, red cell PK (PK-R) of this case was also found to show a similar abnormal electrophoretic mobility (Nakashima et al., 1974). Using several kinetic parameters as well as polyacrylamide gel electrophoresis, we could identify several PK variants (Nakashima et al., 1974; Miwa et al., 1975). At that time, it was noticed that some of the severe PK deficiency cases failed to show PK-R in electrophoresis when hemolysate was used. We thought that these cases were probably caused by the lack of PK-R synthesis probably due to regulatory gene mutation. We called these cases as classical PK deficiency (Miwa et al., 1975). Interestingly, these cases showed $\mathrm{M}_{2}$-type $\mathrm{PK}$ which was not seen in normal red cells, presumably by a compensatory mechanism. However, in a later study using a partially purified PK, it was found that PK-R with abnormal kinetic properties as well as abnormal electrophoretic mobility existed in the red cell (Shinohara et al., 1976). Hence, it has become increasingly apparent that most, if not all, of the PK deficiency is caused by structural gene mutation, and not by decreased synthesis of normal enzyme protein molecules.

A variety of techniques and methods had thus far been used in different laboratories for characterizing PK variants. The investigators in this field began to feel that the use of standard methods for the analysis of PK variants would make it 
Table 1. Main features of seven PK variants found in our laboratory.

\begin{tabular}{|c|c|c|c|c|c|c|c|}
\hline & Tokyo & Nagasaki & Sapporo & Maebashi & Itabashi & Fukushima & Aizu \\
\hline Activity $(\%)$ & 156 & 136 & 147 & 39 & 51 & 92 & 63 \\
\hline $\mathrm{K}_{0.5 \mathrm{~S}}(\mathrm{PEP})$ & $\mathrm{H}$ & $\mathrm{H}$ & $\mathrm{H}$ & $\mathbf{H}$ & $\mathrm{H}$ & $\mathrm{H}$ & $\mathbf{H}$ \\
\hline Hill coeff. & $\mathbf{L}$ & $\mathrm{N}$ & $\mathrm{N}$ & $\mathrm{N}$ & $\boldsymbol{L}$ & slightly $\mathrm{H}$ & $\mathbf{N}$ \\
\hline $\mathrm{K}_{0.5 \mathrm{~S}}(\mathrm{ADP})$ & $\mathbf{L}$ & $\mathrm{L}$ & L & $\mathrm{N}$ & $\mathbf{N}$ & $\mathbf{N}$ & $\mathrm{N}$ \\
\hline $\begin{array}{l}\text { Nucleotide } \\
\text { specificity }\end{array}$ & $\begin{array}{l}\text { slightly } \\
\text { Abn }\end{array}$ & $\mathbf{N}$ & Abn & $N$ & Abn & Abn & Abn \\
\hline ATP inhibition & More & More & More & $\mathrm{N}$ & More & More & More \\
\hline F-1,6-DP activation & $N$ & $\mathbf{N}$ & $N$ & Less & $\mathrm{N}$ & Less & Less \\
\hline Thermostability & $\mathrm{Lab}$ & $\mathbf{L a b}$ & $\mathrm{N}$ & $\mathrm{Lab}$ & Lab & $\mathrm{Lab}$ & $\mathrm{Lab}$ \\
\hline pH curve & Acid & Acid & $N$ & $\begin{array}{l}\mathrm{N} \\
\text { narrow }\end{array}$ & $\begin{array}{l}\mathrm{N} \\
\text { narrow }\end{array}$ & $\mathrm{N}$ & $\mathrm{N}$ \\
\hline $\begin{array}{l}\text { Electrophoretic } \\
\text { mobility }\end{array}$ & Slow & Slow & Fast & $\mathbb{N}$ & Slow & Slow & $\mathrm{N}$ \\
\hline
\end{tabular}

$\mathrm{N}$, normal; $\mathrm{H}$, high; L, low; Abn, abnormal; More, more inhibition than the normal; Less, less activation (more F-1,6-DP required than the normal required for $50 \%$ activation); Lab, labile.

possible to compare results obtained in different laboratories, and to identify variants on the basis of biochemical parameters. Such methods have been developed through a collaborative effort among members of a working group of the International Committee for Standardization in Haematology (ICSH, 1979), in which I played a role as a chairman. The number of essential parameters for abnormal PKs are minimized to ten because of the limitation of both time required for the studies and volume of blood obtainable from a patient. The ten parameters are as follows: 1) PK activity, 2) thermostability, 3) $\mathrm{K}_{0.5 \mathrm{~s}}$ (PEP), 4) Hill coefficient, 5) $\mathrm{K}_{0.5 \mathrm{~s}}$ (ADP), 6) nucleotide specificity, 7) ATP inhibition, 8) fructose 1,6-diphosphate (F-1,6-DP) activation, 9) $\mathrm{pH}$ curve, and 10) thin layer polyacrylamide gel electrophoresis. The first two are determined using crude hemolysate while other parameters are determined using partially purified samples.

As red cell PK activity sometimes decreases in erythroleukemia, acute leukemia, refractory anemia and other hematological disorders (Arnold et al., 1974; Boivin et al., 1975), a family study is essential in order to differentiate hereditary PK deficiency from an acquired PK deficiency. It should be noted at this point that we can characterize a PK variant from the red cell of a homozygous PK deficiency, but it is almost impossible to characterize two PK variants from a heterozygous PK deficiency which is caused by the inheritance of two different mutant PKs. Main features of seven new PK variants characterized by this methods in our laboratory is shown in Table 1 (Miwa et al., 1980a).

\section{G6PD Deficiency in Japan}

Japan locates in the temperate zone and the malaria is not endemic. Presumably for these reasons, G6PD deficiency appears to be rare. However, until recently little 
was known about the frequency in Japanese (Matsunaga et al., 1965; Miwa et al., 1965b). Using the spot test of Beutler and Mitchell (1968) and starch gel electrophoresis, the screening for G6PD deficiency was made recently in males living in Yamaguchi prefecture by us. Initially, a total of 6,120 males were screened using Beutler's spot test and 5 deficiency cases were found (Nakashima et al., 1977). Secondly, 3,000 males were screened using both the spot test and starch gel electrophoresis and 15 cases with the deficiency were found (Nakatsuji and Miwa, 1979). Frequency of G6PD deficiency in Japanese, at least who live in Yamaguchi prefecture, was revealed to be $0.1-0.5 \%$. This value is quite different from those found in southern Chinese $(5.5 \%$ ) (Chan et al., 1964), in Taiwan-Hakka population $(5.5 \%)$ (Lee et al., 1963) and in the Philippines $(6.0 \%)$ (Motulsky et al., 1964). In addition, the variants found in Chinese and Philippines are different from those found in Japanese except for G6PD B(-) Chinese (Nakashima et al., 1977). These differences suggest the possibility that the mutation might have occurred after Japanese were isolated in the islands. In addition, the frequency in Japan could not increase probably because the positive selective pressure of the endemic of malaria was lacking.

Table 2. Main features of $19 \mathrm{G} 6 \mathrm{PD}$ variants found in our laboratory.

\begin{tabular}{|c|c|c|c|c|c|c|c|}
\hline & $\begin{array}{c}\mathrm{Hb} \\
(\mathrm{g} / 100 \mathrm{ml})\end{array}$ & $\begin{array}{c}\text { Retics } \\
(\%)\end{array}$ & $\begin{array}{c}\text { Activity } \\
(\%)\end{array}$ & $\mathrm{K}_{\mathrm{m}} \mathrm{G} 6 \mathrm{P}$ & $\mathrm{K}_{\mathrm{m}} \mathrm{NADP}$ & $\mathrm{K}_{\mathrm{i}} \mathrm{NADPH}$ & $\begin{array}{l}\text { Thermal } \\
\text { stability }\end{array}$ \\
\hline \multicolumn{8}{|l|}{ Class 1} \\
\hline Tokyo & 12.6 & 4.5 & 4.4 & Normal & Normal & Normal & Labile \\
\hline Tokushima & 12.1 & 22.0 & 3.0 & Normal & High & Normal & Labile \\
\hline Ogikubo & 9.2 & 8.4 & 3.0 & Normal & Normal & Normal & Labile \\
\hline Kurume & 10.6 & 4.0 & 0.8 & Normal & Normal & Low & Labile \\
\hline Fukushima & 6.5 & 18.5 & 2.8 & Normal & Normal & Low & Labile \\
\hline Yokohama & 7.5 & 35.2 & 1.9 & Normal & Normal & Low & Labile \\
\hline Yamaguchi & 6.9 & 32.4 & 3.5 & Normal & High & Normal & Labile \\
\hline Wakayama & 10.6 & 3.6 & 4.5 & Normal & Normal & Low & Labile \\
\hline Akita & 11.1 & 15.0 & 0 & Normal & Normal & Normal & Labile \\
\hline \multicolumn{8}{|l|}{ Class 2} \\
\hline Mediterranean-like & se 9.2 & 2.0 & 3.5 & Low & $\begin{array}{l}\text { Slightly } \\
\text { low }\end{array}$ & 一 & $\begin{array}{l}\text { Slightly } \\
\text { labile }\end{array}$ \\
\hline Ogori & 15.9 & 3.3 & 3.5 & Normal & Normal & - & Normal \\
\hline Gifu & 11.1 & $10.7^{*}$ & 1.2 & Normal & Normal & Normal & Labile \\
\hline Fukuoka & 12.4 & 1.8 & 3.4 & High & Normal & Normal & Labile \\
\hline \multicolumn{8}{|l|}{ Class 3} \\
\hline Hofu & 15.1 & 3.2 & 12.1 & Low & Normal & 一 & Normal \\
\hline $\mathrm{B}(-)$ Chinese & 13.1 & 4. 3 & 25.1 & Normal & Normal & High & Normal \\
\hline Ube & 14.0 & 1.0 & 46.4 & Normal & Normal & High & Normal \\
\hline Konan & 13.7 & 0.8 & 42.1 & Normal & Normal & Normal & Normal \\
\hline Kamiube & 12.5 & 1.1 & 45 & Normal & Normal & Normal & Normal \\
\hline Kiwa & 13.0 & 1.0 & 64 & Normal & Normal & Normal & Normal \\
\hline
\end{tabular}


Fifty-four cases of G6PD deficiency have so far been reported in Japan. Among them, 21 G6PD variants have been characterized. Nineteen out of the 21 variants were characterized in our laboratory (Miwa et al., 1976; Nakashima et al., 1977; Miwa et al., 1977a; Miwa et al., 1978a, 1978b; Nakatsuji and Miwa, 1979). Main features of the 19 G6PD variants characterized in our laboratory are shown in Table 2.

\section{Other Red Cell Enzyme Anomalies, Studies in Our Laboratory}

Number of cases of red cell enzyme anomalies mainly associated with hereditary hemolytic anemia found or studied in our laboratory is shown in Table 3. Among them, pyrimidine 5'-nucleotidase (P5N) deficiency and adenosine deaminase overproduction both associated with hereditary hemolytic anemia will be mentioned briefly here.

P5N deficiency was first described by Valentine et al. (1974). Since then, an increasing number of cases of this deficiency has been reported, and it seems likely that this deficiency will prove to be fairly common cause of hereditary hemolytic anemia. In Japan, 3 different families have been found by us recently (Miwa et al., 1977b; Miwa et al., 1980b; Miwa et al., unpublished observation). The hallmark of the deficiency is a marked basophilic stippling of the red cells of the patients. It should be noted that the basophilic stippling seen in lead poisoning was proved to be caused by marked inhibition of red cell P5N by lead (Valentine et al., 1976). Pyrimidine nucleotides increase as a result of P5N deficiency and they probably interfere with adenine nucleotides. As a result, glycolysis is disturbed, resulting in chronic hemolytic anemia.

It has been known that adenosine deaminase deficiency causes severe combined immunodeficiency (Giblett et al., 1972). This disorder is caused by an autosomal recessive trait, and probably caused by structural gene mutation. Recently,

Table 3. Number of cases of red cell enzyme abnormalities mainly associated with hemolytic anemia found in our laboratory.

\begin{tabular}{lr}
\hline Embden-Meyerhof pathway & 7 \\
Glucosephosphate isomerase deficiency & 1 \\
Phosphofructokinase deficiency & 1 \\
Phosphoglycerate kinase deficiency & 42 \\
Pyruvate kinase deficiency & 46 \\
Pentose cycle and glutathione metabolism & 1 \\
G6PD deficiency & 6 \\
Glutathione peroxidase deficiency (heterozygote) & 1 \\
Nucleotide metabolism & 105 \\
Pyrimidine 5'-nucleotidase deficiency & 1 \\
Adenosine deaminase overproduction & 1 \\
\hline Total &
\end{tabular}


Valentine et al. (1977) reported for the first time 12 cases in one family of hereditary hemolytic anemia associated with markedly increased red cell adenosine deaminase (45- to 70-fold) and decreased ATP. The disorder is inherited as an autosomal dominant trait. We found the second family of this disorder (Miwa et al., 1978c). As it is quite interesting to know whether this disorder is caused either by an overproduction of normal enzyme protein or by synthesis of mutant enzyme protein molecules with increased specific activity due to structural gene mutation, we wanted to clarify this point. Red cell adenosine deaminase from normal control subjects and from a case of this disorder were purified using antibody affinity chromatography. No differences could be found between them in molecular weight, specific activity, polyacrylamide gel electrophoresis, Michaelis constant for adenosine, inhibition constant for guanylurea, utilization of 2-deoxyadenosine, thermal stability, optimum $\mathrm{pH}$, immunological reactivity, amino acid composition as well as tryptic map (Miwa et al., unpublished observation). These results strongly suggest that the increased red cell adenosine deaminase activity seen in the patient is caused by an overproduction of a structurally normal enzyme, presumably by a regulatory gene mutation.

\section{Future Prospects}

Much will be learned about the mechanism of hemolysis from the studies to see biochemical characteristics of mutant enzymes. However, the next step should be the determination of amino acid substitution or deletion of the mutant enzyme molecules as well as the determination of primary structure of normal human red cell enzymes. As compared to hemoglobin, concentrations of enzymes in the red cells are much lower than that of hemoglobin and the molecular weights are in general larger than that of hemoglobin. Primary structures of the red cell enzymes which we are dealing with are mostly unknown.

Amino acid substitution has been proven in two G6PD variants, G6PD A+ (Yoshida, 1967) and G6PD Hektoen (Yoshida, 1970). These two variants fortunately had only modestly decreased activity or even higher than normal activity. In order to achieve the determination of amino acid substitutions of the deficient enzymes, development of very good ultramicro analytical methods suitable for these studies are badly needed.

Storage of cells with rare mutant enzymes is also important. This can be achieved either by culture of skin fibroblasts or by culture of lymphocytes of the patients, provided that the particular enzyme of fibroblasts of lymphocytes and red cells is governed by the same structural gene. For the culture of lymphocytes, treatment with $\mathrm{EB}$ virus is necessary.

Animal model such as PK deficient Basenji dog is quite useful for biochemical studies as well as for the search for an appropriate treatment of the disorders. For example, bone marrow transplantation has been shown to be successful in PK 
deficient Basenji dog (Weiden et al., 1976).

The final goal is to find the way to treat the patients satisfactorily. At present, splenectomy is moderately effective in many cases. Satisfactory treatment of the patients is by no means easy, but hopefully will be achieved in near future by either biochemical means or by genetic means.

Acknowledgements These studies were in part supported by the scientific research grants from the Ministry of Education, and the Ministry of Health and Welfare, Japan.

\section{REFERENCES}

Arnold, H., Blume, K.G., Löhr, G.W., Boulard, M., and Najean, Y. 1974. Acquired red cell enzyme defects in hematological diseases. Clin. Chim. Acta 57: 187-189.

Beutler, E., and Mitchell, M. 1968. Special modification of the fuorescent screening method for glucose 6-phosphate dehydrogenase deficiency. Blood 32: 816-818.

Boivin, P., Galand, C., Hakim, J., and Kahn, A. 1975. Acquired erythroenzymopathies in blood disorders; Study of 200 cases. Brit. J. Haemat. 34: 531-543.

Carson, P.E., Flanagan, C.L., Ickes, C.E., and Alving, A.S. 1956. Enzymatic deficiency in primaquine-sensitive erythrocytes. Science 124: 484-485.

Chan, T.K., Todd, D., and Wong, C.C. 1964. Erythrocyte glucose-6-phosphate dehydrogenase deficiency in Chinese. Brit. Med. J. 2: 102.

Giblett, E.R., Anderson, J.E., Cohen, F., Pollara, B., and Meuwissen, H.J. 1972. Adenosine deaminase deficiency in two patients with severy impaired cellular immunity. Lancet 2:10671069.

Imamura, K., and Tanaka, T. 1972. Multimolecular forms of pyruvate kinase from rat and other mammalian tissues. I. Electrophoretic studies. J. Biochem. 71: 1043-1051.

Imamura, K., Tanaka, T., Nishina, T., Nakashima, K., and Miwa, S. 1973. Studies on pyruvate kinase (PK) deficiency. II. Electrophoretic, kinetic and immunological studies on pyruvate kinase of erythrocytes and other tissues. J. Biochem. 74: 1165-1175.

International Committee for Standardization in Haematology (ICSH) 1979. Recommended methods for the characterization of red cell pyruvate kinase variants. Brit. J. Haemat. 43: 275-286.

Koler, R.D., Bigley, R.H., and Stenzel, P. 1968. Biochemical properties of human erythrocyte and leukocyte pyruvate kinase. In Hereditary Disorders of Erythrocyte Metabolism. E. Beutler, ed., Grune \& Stratton, New York, pp. 249-259.

Lee, T.C., Shin, L.Y., Huang, P.C., Lin, C.C., Blackwell, B.N., Blackwell, R.Q., and Hsia, D.Y.Y. 1963. Glucose-6-phosphate dehydrogenase deficiency in Taiwan, Am. J. Hum. Genet. 15: 126-132.

Löhr, G.W., Waller, H.D., and Karges, O. 1957. Quantitative Fermentbestimmungen in roten Blutzellen. Klin. Wschr. 35: 871-875.

Matsunaga, E., Shinoda, T., and Handa, A. 1965. A genetic study of the variation of erythrocyte glucose-6-phosphate dehydrogenase of apparently healthy Japanese. Ipn. J. Human Genet. 10: $1-12$.

Minakami, S., Suzuki, C., Saito, T., and Yoshikawa, H. 1965. Studies on erythrocyte glycolysis. I. Determination of the glycolytic intermediates in human erythrocytes. J. Biochem. 58: 543-550.

Miwa, S., and Nagata, M. 1965a. Pyruvate kinase deficiency hereditary nonspherocytic hemolytic anemia. Report of two cases in a Japanese family and review of literature. Acta Haem. Jpn.

Jpn. J. Human Genet. 
28: $1-13$.

Miwa, S., Teramura, K., Irisawa, K., and Ohyama, H. 1965b. Glucose-6-phosphate dehydrogenase(G-6-PD) deficiency. II. Incidence of G-6-PD deficiency in Japanese. Acta Haem. Jpn. 28: 590-592.

Miwa, S., Nakashima, K., Ariyoshi, K., Shinohara, K., Oda, E., and Tanaka, T. 1975. Four new pyruvate kinase (PK) variants and a classical PK deficiency. Brit. J. Haemat. 29: 157-169.

Miwa, S., Ono, J., Nakashima, K., Abe, S., Kageoka, T., Shinohara, K., Isobe, J., and Yamaguchi, H. 1976. Two new glucose 6-phosphate dehydrogenase variants associated with congenital nonspherocytic hemolytic anemia found in Japan. $\mathrm{Gd}(-)$ Tokushima and $\mathrm{Gd}(-)$ Tokyo. Am. J. Hemat. 1 : 433-442.

Miwa, S., Nakashima, K., Fujii, H., Matsumoto, N., and Nomura, K. 1977a. Three cases of hereditary hemolytic anemia with pyrimidine $5^{\prime}$-nucleotidase deficiency in a Japanese family. Human Genet. 37 : 361-364.

Miwa, S., Nakashima, K., Ono, J., Fujii, H., and Suzuki, E. 1977b. Three glucose 6-phosphate dehydrogenase variants found in Japan. Human Genet. 36: 327-334.

Miwa, S., Fujii, H., Nakashima, K., Miura, Y., Yamada, K., Hagiwara, T., and Fukuda, M. 1978 a. Three new electrophoretically normal glucose-6-phosphate dehydrogenase variants associated with congenital nonspherocytic hemolytic anemia found in Japan: G6PD Ogikubo, Yokohama and Akita. Human Genet. 45: 11-17.

Miwa, S., Fujii, H., Nakatsuji, T., Ishida, Y., Oda, E., Kaneto, A., Motokawa, M., Ariga, Y., Fukuchi, S., Sasai, S., Hiraoka, K., Kashii, H., Kodama, T., and Miura, Y. 1978b. Four new electrophoretically slow-moving glucose 6-phosphate dehydrogenase variants associated with congenital nonspherocytic hemolytic anemia found in Japan: $\mathrm{Gd}(-)$ Kurume, Gd(-) Fukushima, Gd(-) Yamaguchi and Gd(-) Wakayama. Am. J. Hemat. 5: 131-138.

Miwa, S., Fujii, H., Matsumoto, N., Nakatsuji, T., Oda, S., Miura, Y., Asano, H., and Asano, S. 1978c. A case of red-cell adenosine deaminase overproduction associated with hereditary hemolytic anemia found in Japan. Am. J. Hemat. 5: 107-115.

Miwa, S., Fujii, H., Takekawa, S., Nakatsuji, T., Yamato, K., Ishida, Y., and Ninomiya, N. 1980a. Seven pyruvate kinase variants characterized by the ICSH recommended methods. Brit. $J$. Haemat. 46, in press.

Miwa, S., Ishida, Y., Kibe, A., Uekihara, S., and Kishimoto, S. 1980b. Two cases of hereditary hemolytic anemia with pyrimidine 5'-nucleotidase deficiency. Acta Haem. Jpn. 43, in press.

Motulsky, A.G., Stransky, E., and Fraser, G.R. 1964. Glucose-6-phosphate dehydrogenase (G6PD) deficiency, thalassemia and abnormal haemoglobins in Philippines. J. Med. Genet. 1: 102106.

Nakashima, K., Miwa, S., Oda, S., Tanaka, T., Imamura, K., and Nishina, T. 1974. Electrophoretic and kinetic studies of mutant erythrocyte pyruvate kinases. Blood 43: 537-548.

Nakashima, K., Ono, J., Abe, S., Miwa, S., and Yoshida, A. 1977. G6PD Ube, a glucose-6-phosphate dehydrogenase variant found in four unrelated Japanese families. Am. J. Hum. Genet. 29: $24-30$.

Nakatsuji, T., and Miwa, S. 1979. Incidence and characteristics of glucose-6-phosphate dehydrogenase variants in Japan. Human Genet. 51: 297-305.

Ohyama, H., Kumatori, T., Nishina, T., and Miwa, S. 1969. Functionally abnormal pyruvate kinase in congenital hemolytic anemia. Acta Haem. Jpn. 32: 330-335.

Paglia, D.E., Valentine, W.N., Baughan, M.A., Miller, D.R., Reed, C.F., and McIntyre, O.R. 1968. An inherited molecular lesion of erythrocyte pyruvate kinase. Identification of a kinetically aberrant isozyme associated with premature hemolysis. J. Clin. Invest. 47: 1929-1946.

Selwyn, J.G., and Dacie, J.V. 1954. Autohemolysis and other changes resulting from the incubation in vitro of red cells from patients with congenital hemolytic anemia. Blood 9: 414 438 .

Shinohara, K., Miwa, S., Nakashima, K., Oda, E., Kageoka, T., and Tsujino, G. 1976. A new 
pyruvate kinase variants (PK Osaka) demonstrated by partial purification and condensation. Am. J. Hum. Genet. 28: 474-481.

Tanaka, K.R., Valentine, W.N., and Miwa, S. 1962. Pyruvate kinase (PK) deficiency hereditary nonspherocytic hemolytic anemia. Blood 19: 267-295.

Valentine, W.N., Tanaka, K.R., and Miwa, S. 1961. A specific erythrocyte glycolytic enzyme defect (pyruvate kinase) in three subjects with congenital non-spherocytic hemolytic anemia. Trans. Ass. Am. Physicians 74: 100-110.

Valentine, W.N., Fink, K., Paglia, D.E., Harris, S.R., and Adams, W.S. 1974. Hereditary hemolytic anemia with human erythrocyte pyrimidine 5 -nucleotidase deficiency. $J$. Clin. Invest. 54: $866-879$.

Valentine, W.N., Paglia, D.E., Fink, K., and Modokoro, G. 1976. Lead poisoning: Association with hemolytic anemia, basophilic stippling, erythrocyte pyrimidine 5 -nucleotidase deficiency, and intracrythrocytic accumulation of pyrimidines. J. Clin. Invest. 58: 926-932.

Valentine, W.N., Paglia, D.E., Tartaglia, A.P., and Gilsanz, F. 1977. Hereditary hemolytic anemia with increased red cell adenosine deaminase (45- to 70-fold) and decreased adenosine triphosphate. Science 195: 783-785.

Weiden, P.L., Storb, R., Graham, T.C., and Schroeder, M.L. 1976. Severe hereditary haemolytic anaemia in dogs treated by marrow transplantation. Brit. J. Haemat. 33: 357-362.

WHO Scientific Group, 1967. Standardization of procedures for the study of glucose-6-phosphate dehydrogenase. WHO Technical Report Series 366: 1-53.

Yoshida, A. 1967. A single amino acid substitution-asparagine to aspartic acid-between normal $(B+)$ and the common Negro variant $(A+)$ of human glucose-6-phosphate dehydrogenase. Proc. Soc. Natl. Acad. Sci. L.S.A. 57: 835-840.

Yoshida, A. 1970. Amino acid substitution (histidine to tyrosine) in a glucose-6-phosphate dehydrogenase variant (G6PD Hektoen) associated with over-production. J. Mol. Biol. 52: $483-490$. 